\title{
THE FORGOTTEN KNOWLEDGE - SHOEMAKING TOOLS FROM OLD TIME
}

\author{
Iliya Valev1, Rositsa Bineva² \\ ${ }^{1}$ Regional Museum of History - Veliko Tarnovo, Bulgaria, ilia_valev85@mail.bg \\ 2 Regional Ethnographic Open-air Museum "Etar", Gabrovo, Bulgaria, \\ r.bineva@etar.bg
}

\begin{abstract}
The article is a result of good collaboration between representatives of two separate institutions engaged with the research, preservation and promotion of cultural and historical heritage. The text presents shoemaking tools that with the time become obsolete and now are no longer in use in the craft. This way they are not only "forgotten" by the modern shoemakers but it is also very difficult to be identified as purpose and function. The idea of the authors is to share their experience during the research and systematization of the facts, that go along with the identification of the objects, that are becoming a part of the museums funds. How the maximum information is benefited with the help of the experts, craftsman and other specialists to rediscover the function of those instruments and their meaning as a cultural valuables.
\end{abstract}

Keywords: Shoemaking; Tools; Cultural Heritage; Craft

\section{ЗАБРАВЕНОТО ЗНАНИЕ - ОБУЩАРСКИ ИНСТРУМЕНТИ ОТ СТАРО ВРЕМЕ}

\author{
Илия Вьлев', Росица Бинева ${ }^{2}$ \\ 1 Регионален исторически музей - Велико Търново \\ 2 Регионален етнографоски музей на открито „Етьр” - Габрово
}

Резюме: Статията е плоА на Аобрата сьвместна работа межАу преАставители на Аве отАелни институции, занимаващи се с изАирването, съхраняването и популяризирането на културноисторическото наследство. Тя представя обущарски инструменти, които в голямата си част отАавна са излезми от употреба при занаята обущарство. Така те не само са „забравени" от съвременните обущари, но и трудно биват разпознавани като предназначение и фрункция. Ето защо илеята на авторите е $л а$ споделят своя опит при проучването и систематизирането на Аанните, които сьпьтстват иАентификацията на преАметите, постьпващи във фрондовете на музеите. Как се извлича максимална информация с помощта на експерти, майстори и Аруги специалисти, за $\Delta$ a cе преоткрие фуункцията на тези инструменти и тяхното значение като културна ценност.

Ключови Ауми: Обущарство, инструменти, културно наслеАство, занаят 
В исторически п^ан занаятьт обущарство възниква върху основата на папукчийството и чехларството. Ао Анес той се приема за най-сложната и специализирана форма на произво Аство на обувни принаАлежности и както преАи, така
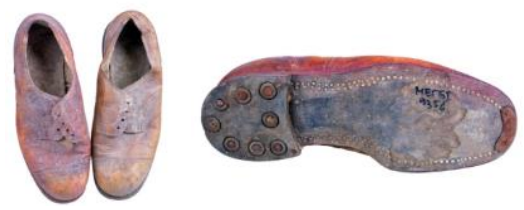
и сега има за цел $А$ а заловолява изискванията на потребителите за зАрави, красиви, удобни и практични обувки. Обущарството се обособява у нас като самостоятелна произволствена фрорма еАва към средата на XIX век, когато на българския пазар (тогава все още в рамките на Османската империя) навлизат т.нар. „клечени обувки" (виж фоиг. 1.1. и 1.2.). Първоначално този занаят се развива изКАючително в гралските центрове, но през 1920-те години бързо и трайно завоюва позиции и по селата. МежАувременно още в началото на XX век в България отварят врати и първите обущарски фрабрики', които от еАна страна $А$ ават тАасък на серийното фабрично произволство, а от Аруга сериозно започват $\Delta$ а конкурират Аребния занаятчийски обущарски сектор и карат много майстори обущари $а$ тьрсят възможности за модернизиране и механизиране на работилниците си и за вкарване на Аопьлнителни работни процеси като кърпачество и ремонт на отАеАни елементи по обувката (Hinkov, 1926: 118, 128-129), (Popov, 1933: 87-128), (Georgiev, 1979: 31-32). Именно тази бърза адаптивност и приспособяването на обущарите кьм нуждите на новото време спасява занаята от изчезване. Нещо повече - $р$ ребното обущарство не само че не се загубва, но дори развива своя пазарна ниша и в наши Ани. С приспособяването си към съвременните условия обаче, занаятьт тьрпи както модернизиране и разширяване на асортимента си от услуги, така и осъществява изменение в организацията и производствената си форма. Анес наблюденията у нас показват, че занаятьт обущарство е насочен преди всичко към ремонт и поААръжка

1 Пьрвата българска обущарска орабрика „Янтра" отваря врати в грал Габрово през 1908 г. (Popov, 1933: 104). 
на различни виАове обувни принаАлежности, както и на разни Аруги кожени изделия и аксесоари, а изработката на нови обувки е преАимно с меАицинско-ортопеАична цеА - в Аейности, в които ръчният труд не може $а$ а бъде полменен.

Всъщност, паралелно с тези промени, през годините изменения очаквано се наблюдават и в инструментариума на обущарските работилници. Така например в резултат на механизирането на работния процес не малко ръчни инструменти постепенно отпалат от производството, а в послеАствие и биват „изхвърляни" като ненужни предмети от работните маси. Изкарването им от употреба обаче води И $\Delta$ о това, че в наши Ани голяма част от инструментариума на някогашните майстори трудно бива разпознаван като предназначение И фрункция. ИАентифоицирането на старите инструменти затруднява дори съвременните обущари, което само по себе си вече е обезпокоителен фракт, преАвиА потенциалната опасност от пьлното заличаване на еАно традиционно знание от миналото ни. Ето защо настоящата статия си поставя за цел $а$ п представи и опише максимално подробно голям набор от стари обущарски инструменти и пособия, съхранявани във фондовете на Регионален исторически музей - Велико Търново. По този начин тя ще изпьлни няколко научни залачи, а именно: ще проследи от по-различен ьгьл историческия развой на тази тралиционна профресия; ще съхрани в Аигитална форма и ще популяризира знанието за тези занаятчийски орьдия на трула пред по-широка аулитория, като така ще увеличи и Аостьпа $А$ ио културното ни материално наследство; ще бъле в помощ на специализираните музейни комисии при иАентиорикация на постьпили в музейните фрондове занаятчийски предмети, както и ще $\Delta а л е$ възможност на изслеАователи от страната и чужбина $А$ прослеАяват и сравняват общото и различното в занаятчийските технологии и в използвания тралиционен инструментариум.

Статията е плол на Аобрата съвместна работа межАу представители на две отАелни институции, занимаващи се с изаирването, съхраняването и популяризирането на културноисторическото наследство. Чрез нея се сполеля опит при проучването и 
систематизирането на Аанните, които съпьтстват идентифоикацията на предметите, постьпващи във фондовете на музеите. При представянето на отАелните инструменти и Аругите обущарски пособия, освен описанието от инвентарните музейни книги, се използва и Аопьлнителна инорормация, извлечена от Аруги изслеАвания (Nabalov, 1985: 168-172), (Tsanov, Kovachev, Totevski,

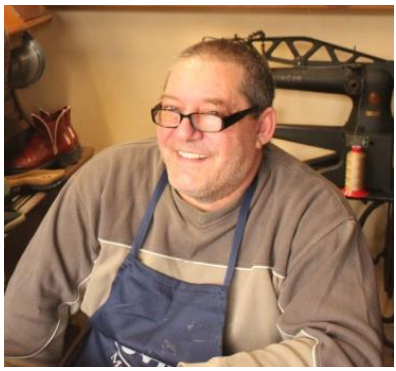

Фиг. 2. Хр. Христофоров

1992: 50-53), както и от проведени непосредствени интервюта с

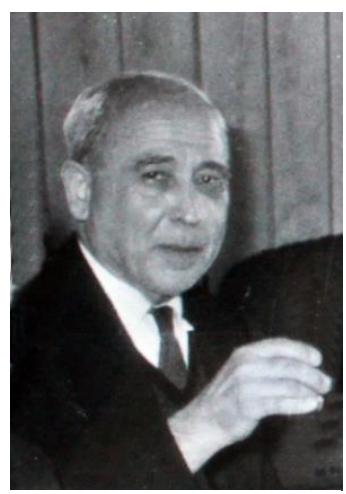

Фиг. 3. М. БуАаков

(Инв. № 580 E.X. /

ОИМ-вт) майстора-обущар Христофрор Христофоров ${ }^{2}$ (Фиг. 2) в грал Габрово през 2020 г. Важна подробност е, че по време на интервютата не само се разказва, но и нагледно се показва работата със съответните инструменти, като Аемонстрациите са заснети с фротографрска и видеотехника. Част от получения визуален материал ще бьле използван за направата на вилео-орилми с образователна и популяризаторска цел.

Настоящият труд не би бил възможен без инструментите и Аругите обущарски пособия, които в по-голямата си част, са приналлежали на

2 Христофрор Вьрбанов Христофоров е ролен през 1961 г. в грал Бургас. Интересното при него е, че слеА като завьршва Минния техникум в грал ТвьрАица е разпрелелен да работи на рудник Качулка. Там обаче не се зальржа Аьлго и, СлеА като напуска мината, се налага Аа изпробва редица Аруги профресии. В последствие отива $А$ работи и в ортопеАичната работилница към Републиканския центьр за летски паралич в грал Котел, кълето започва да се обучава в занаята обущарство. От Центьра в Коте^ за кратко е изпратен в Софрия. Там той успява Аа усвои и както сам казва „Аа откраАне от послеАните стари майстори-обущари много тънкости на занаята". През 1979 г. Христофроров получава свидетелство за майстор-обущар и пьрвоначално продьлжава Аа работи в Котел. През 1981 г. обаче се премества в Габрово като $А$ Анес практикува занаята си там. Член е на Националната занаятчийска камара и по негови Ауми „е най-Аобрият обущар в областта, а клиентите не са само от Габрово и региона". Неговата интересна история и профеесионална практика обаче ще бъде обект на Аруго изслелване. 
Марин Христов Будаков ${ }^{3}$ (фриг. 3), утвьрден обущар-молемиер и ботушар не само във Велико Търново, но и в цяла България. Интересна полробност за него е, че през 1928 г. като калфра при майстора Христо Аобаров в Търново той пьрви изработва шити Аамски обувки в старопрестолния граА 4 , а малко по-късно - вече като самостоятелен майстор-обущар, пьрви започва да произвежАа и мьжки и Аамски обувки от змийска и жабешка кожа. ОтАелно е необхолимо $\Delta а$ се каже още, че колекцията от обущарски инструменти и пособия на Марин Булаков е мобре запазена и реално показва етап от развитието на обущарството от втората половина на XIX век $\Delta$ о средата на XX век 5 . Същото важи и за останалите обущарски инструменти, преАставени в статията. Те също са в добро общо състояние, като дьлго време не са използвани. Открити са при разчистване на старо ск^алово помещение и са инвентирани в музейния фонА на РИМ-Велико Търново през 2016 г.

\footnotetext{
3 Марин Христов Будаков е роден през 1904 г. в град Аясковец. Пьрвоначално е чиракува^ и работи^ като калфра при майсторите-обущари Никола Аряновски в Аясковец, Пенчо Аочев в Русе и Христо Аобаров в Търново, а впослеАствие, на 25 януари 1929 г., той е провьзгласен за „гралски майстор по занаята Обущарство" от Варненската търговско-индустриална камара. През ноември 1940 г. Марин Будаков отваря и търговски магазин със сеАалище във Велико Търново. Предметьт му на Аейност е „продажба на всички виАове обущарски материали и инструменти, вСички виАове готови обувки, га^оши и шушони на Аребно и еАро и Аоставка на търгове". (Източници: снимки и Аокументи от фооновете на РИМВелико Търново поА инв. № № 559 Е-Х / ОИМ-ВТ; 562 Е-Х / ОИМ-ВТ; 582 Е-Х / ОИМ-ВТ; 583 Е-Х / ОИМ-ВТ и на АА-Велико Търново - фо. 90к, оп. 4, а.е. 1464, ^. 1, 3).

${ }^{4}$ Ао 1930-те и 1940-те години не само в Търново, но и на много места в страната все още най-разпространени като производство са клечените обувки. Шиенето и ^епенето на обувки навлиза и се разпространява бавно като обущарска практика.

5 Колекцията от обущарски инструменти и пособия постьпва в РИМ-Велико Търново през 2005 г. благодарение Аарението на Христо Болаков, син на Марин Будаков. Инструментите са описани и инвентирани от Недка Филева, Галя Чохалжиева и Налка Василева-Борисова.
} 


\section{КРАТЪК КАТАЛОГ НА СТАРИ ОБУЩАРСКИ ИНСТРУМЕНТИ И ПОСОБИЯ}
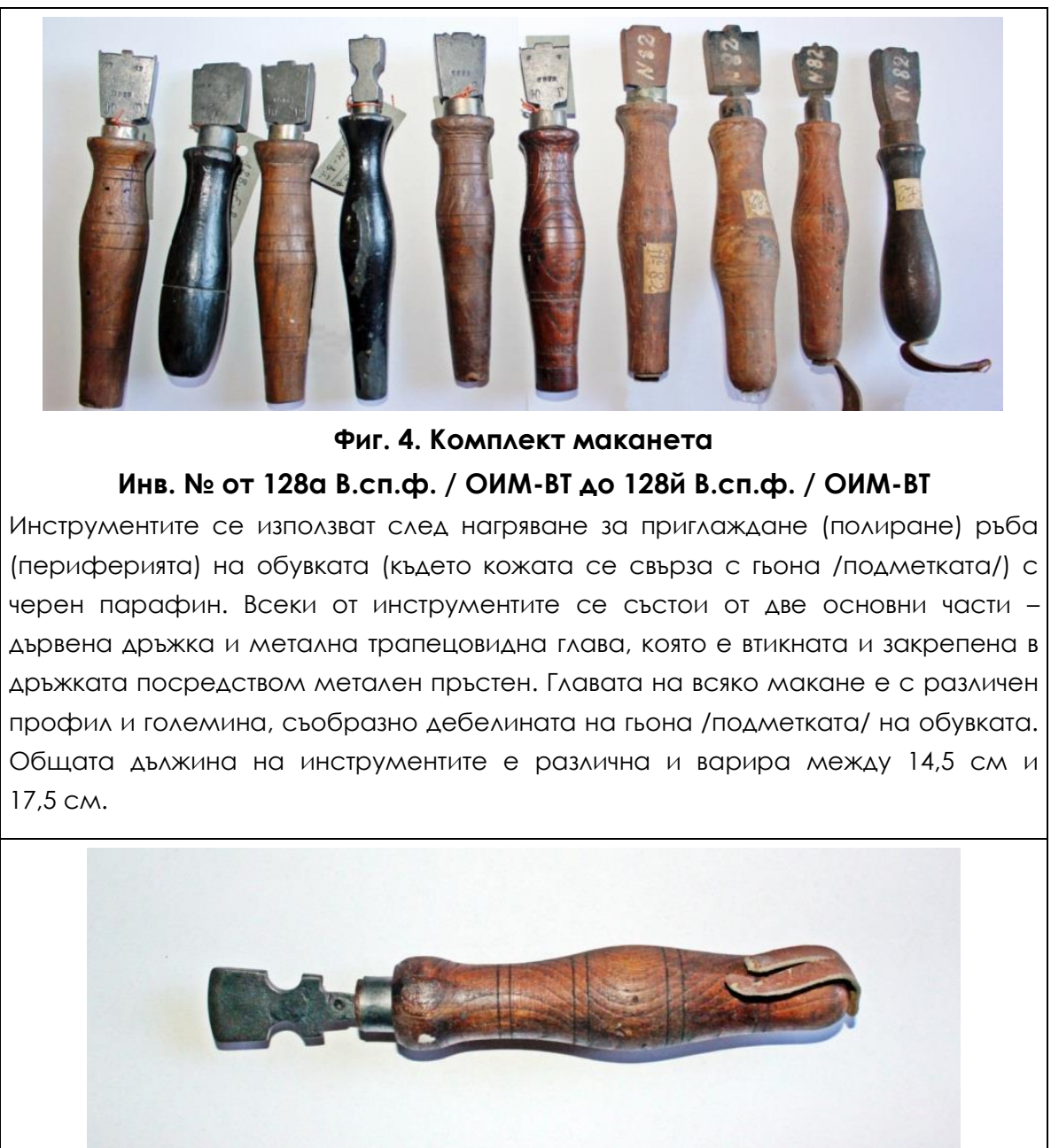

Фиг. 5. Макане -

Инв. № 127 В.сп.ф. / ОИМ-ВТ.

Инструментьт се използва слеА нагряване за приглажАане (полиране) рьба (перифрерията) на обувката (кьлето кожата се свьрза с гьона /подметката/) с черен парафрин. Сьстои се от Аве основни части - дьрвена дрьжка, завьршваща 
с кожена окачалка и метална плоска глава с неправилна правоъгълна фрорма. ГАавата е втикната и закрепена в Аръжката посрелством метален прьстен. Върхьт на главата завьршва с плитко каналче. Обща Аьлжина на инструмента: 18,5 см.

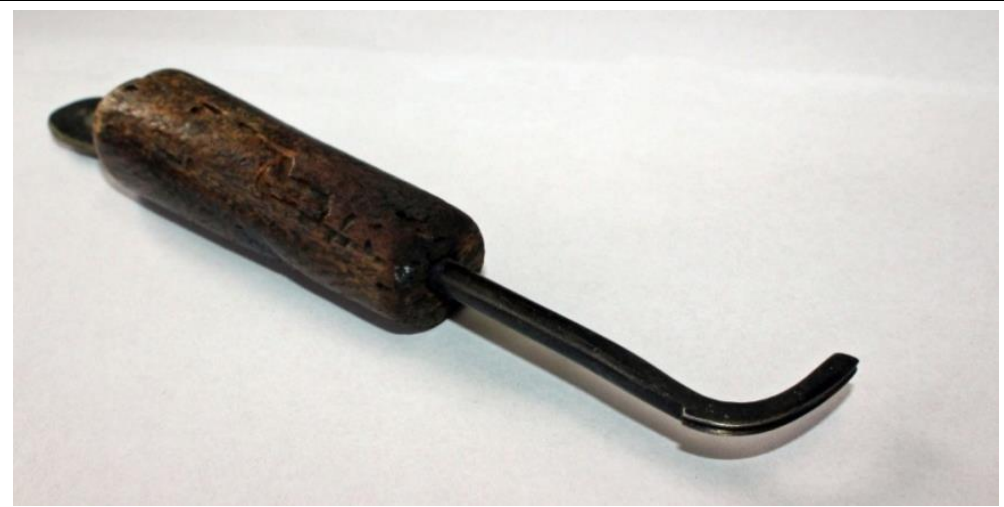

Фиг. 6. Макане -

\section{Инв. № 751 Е.М. / ОИМ-ВТ.}

Използва се за оформяне на кинарите (ръбовете, издалените навън от лице на обувка части от полметката) на обувките. Инструментьт е метален и има Г-образна орорма. Горната му извита част е с офрормено плитко каналче. Аругият край е заострен и втикнат в Аьрвената цилинАрична Аръжка. Завършва с кожена окачалка. Аьлжина на металната част: 6 см. Аьлжина на Аръжката: 8 см.

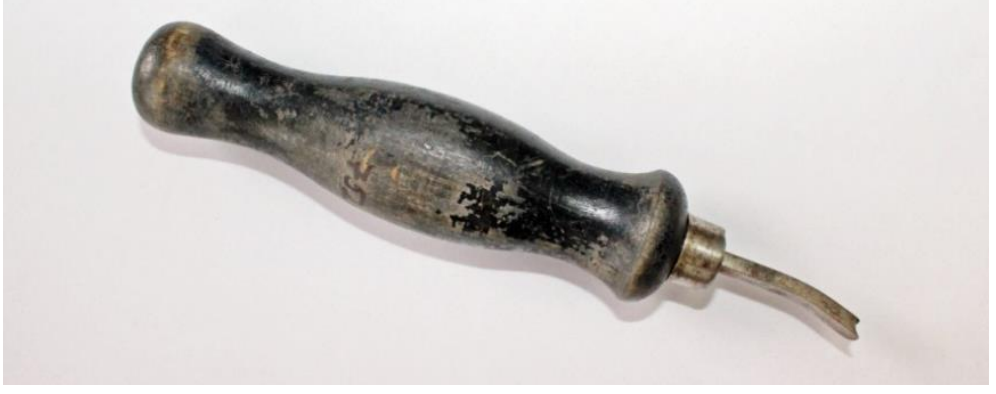

Фиг. 7. Щупел, Аребен -

Инв. № 752 Е.М. / ОИМ-ВТ.

Служи за направа на каналчета (вл^ьбнатини) върху кинара (ръба, издалената навън от мице на обувка част от полметката) на обувката, за да мине конецьт. Използва се при изработването на обувки с гьон и пришит, издален навън от 
мицето на обувката край на полметката. Инструментьт представлява къс четвъртит метален лост с ^еко извит врьх, завьршващ с улейче. Аругият край е втикнат в Аьрвена цилиндрична Аръжка и закрепен с метална халка. Обща Аь^жина на инструмента: 16,4 см.

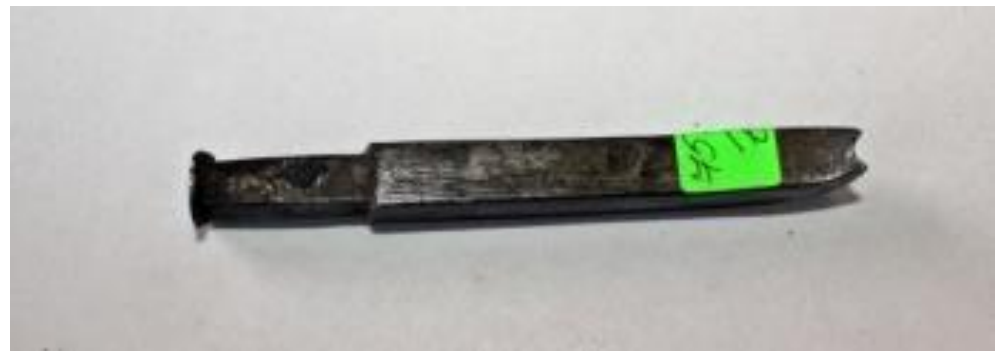

Фиг. 8. Щупел, еАър -

Инв. № 753 E.M. / ОИМ-ВТ.

Служи за направа на каналчета (вА^ъбнатини) върху кинара (рьба, изАалената навън от лице на обувка част от полметката) на обувката, за да мине конецьт. Използва се при изработването на обувки с гьон и пришит, изАален навън от мицето на обувката край на подметката. Инструментьт представлява къС метален ^ост в правоъґлна издьлжена орорма. В елиния край е леко извит, като завършва с улей. Без Аръжка. Аьлжина: 7,7 см. Ширина: 0,7 см.
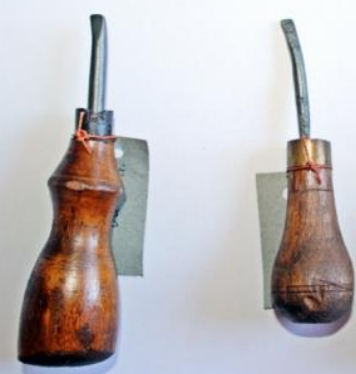

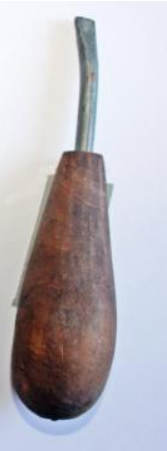

Фиг. 9. Комплект щупели за Аеспонт -

Инв. № от 129а В.сп.ф. / ОИМ-ВТ АО 129в В.сп.ф. / ОИМ-вТ.

Използват се за гравиране и украса (Аеспонт на обувката), което се прави от тока Ао върха на холилото и обратно. Служат още и за прокарване на дебела врьзка и/или кожена каишка през специално направени за целта Аупки по обувката. Всеки от инструментите се състои от Аве основни части - Аьрвена крушовиАна Аръжка и метална леко извита п^ьтна трьбичка, завьршваща с плитко улейче. Металната част е втькната и фиксирана в Аръжката посрелством метален прьстен. Общата Аьлжина на инструментите е различна и варира межАу 11 см и 14,5 cм. 


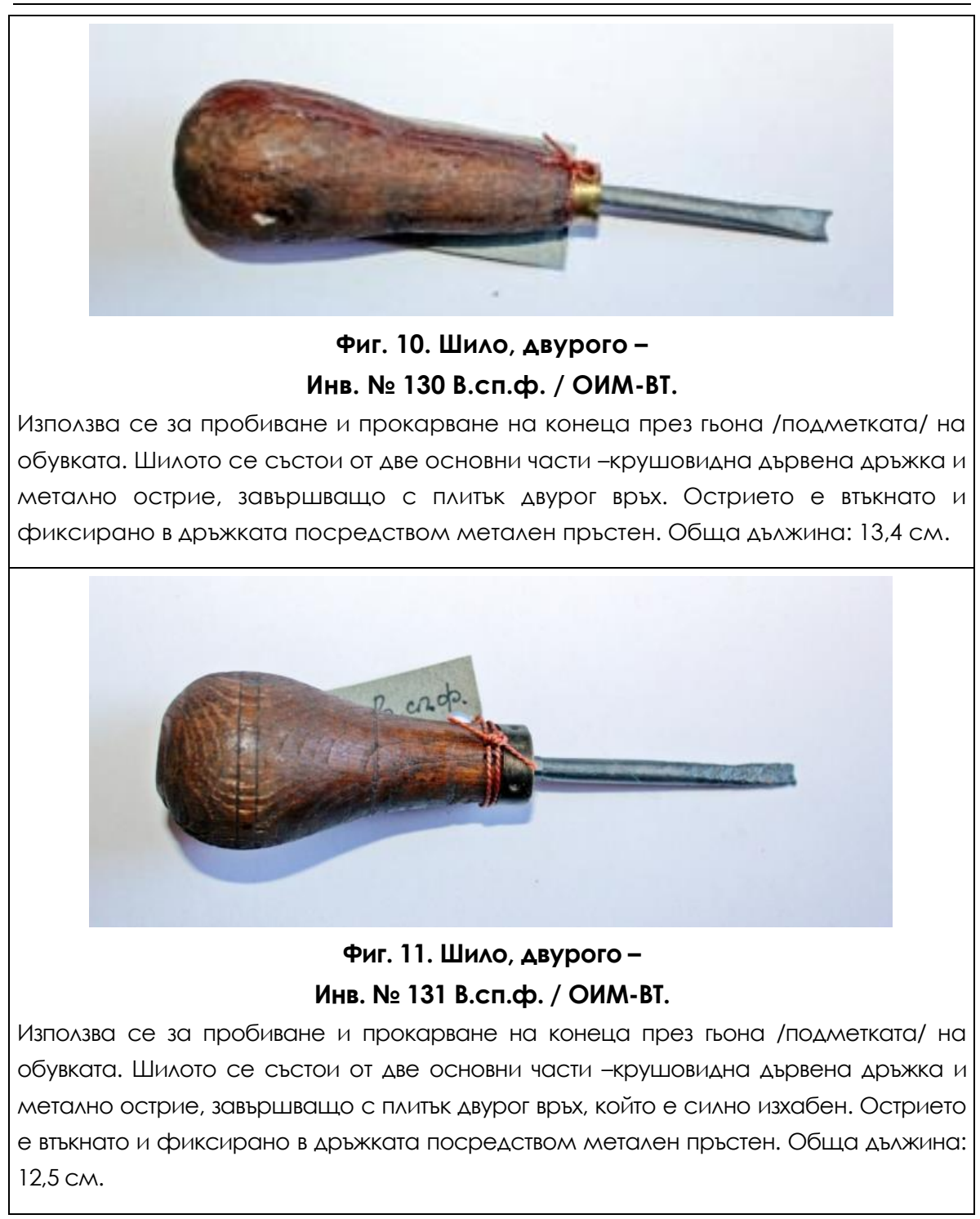




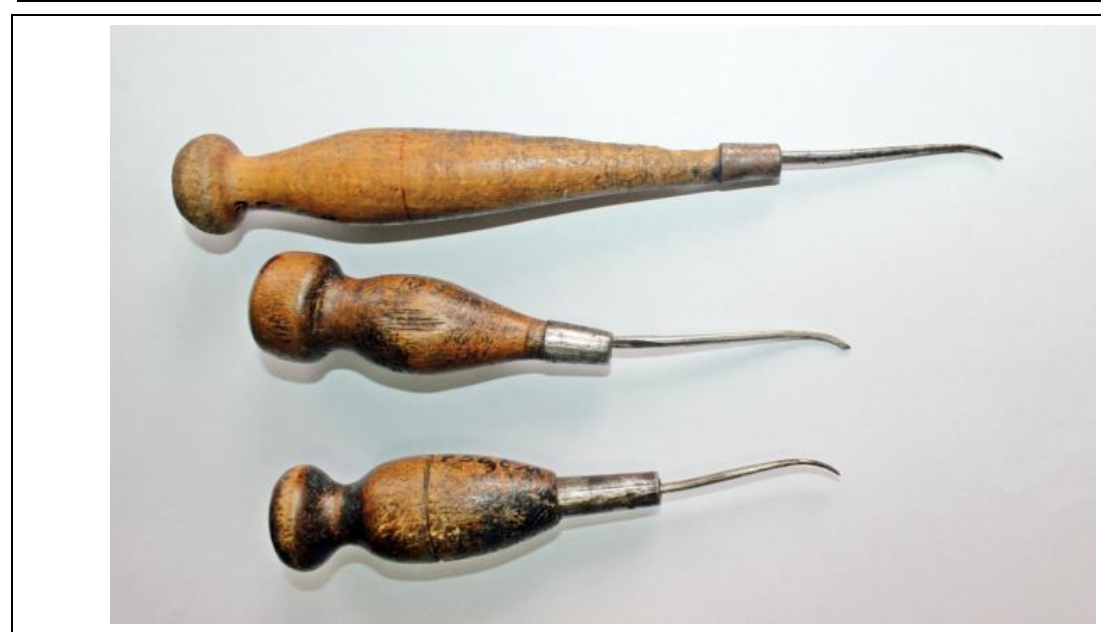

Фиг. 12. Комплект шила за шиене на гьонове и рами -

Инв. № от 756а Е.М. / ОИМ-вт Ао 756в Е.М. / ОИМ-Вт.

Служат за прехващане на саята (скроено и съшито ^ице на обувка, преди $а$ а се

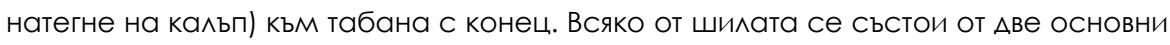
части - Аьрвена изАьлжена крушовиАна Аръжка с топчеста глава от еАиния край и Аьлго метално острие с тънък и ^еко извит връх. Острието е втикнато в Аървената Арьжка и закрепено с цилиндрична метална халка. Общата Аьлжина на инструментите е различна и варира между 14,6 см и 21,5 см.

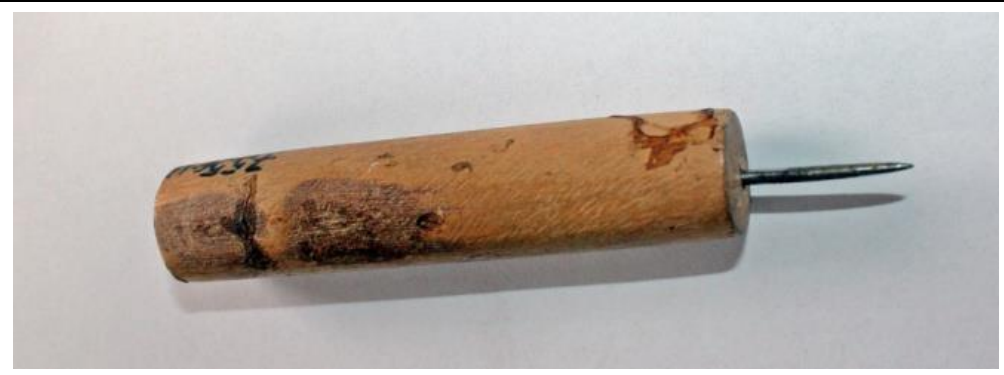

Фиг. 13. Шило, качаброк или още чепилер Инв. № от 755 Е.М. / ОИМ-ВТ.

Обущарски инструмент, служещ за пробиване на Аупки при набиване на клечките. ПреАставлява тънък, не много Аьльг и силно заострен отпреА шип, който е втикнат в цилиндрична Аьрвена Аръжка. Обща Аьлжина: 10,7 см. 


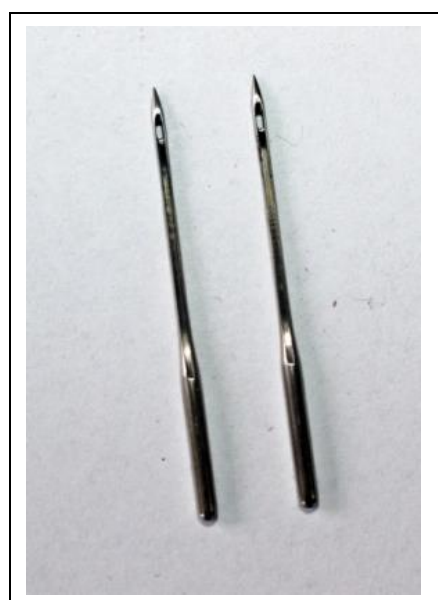

\section{Фиг. 14. ИгАи, обущарски -}

\section{Инв. № от 777 Е.М. / ОИМ ВТ.}

Иглите са метални. В еАиния им край те са обли и с крьгло сечение, а в Аругия са скосени и завьршват с тьньк остьр връх, на който е пробит отвор за провиране на конеца. От върха започва улейче, което продьлжава Ао облата част на иглата. Това улейче спомага за направа на качествен шев. Аьлжина: 3,8 см.

Фиг. 15. (Х)амбус -

\section{Инв. № 133 В.сп.ф. / ОИМ-ВТ.}

Инструментьт служи за разпьване и гланциране на кожата на обувката, която преди това е захваната за кальпа с гвоздейчета. Слел неговото загравяне, (х)амбусьт разтапя и заглажАа греса и черния воськ, които предварително са намазани върху кожата. Използва се и при полиране на табаните на обувките. Инструментьт се състои от Аве основни части - Аьрвена цилинАрична Аръжка и метален корпус, имащ фоормата на островрьха, скосена от енната страна обувка, с глаАка основа и стьпаловиАна залница. Металната част е втикната и закрепена за дръжката посредством метален прьстен. Обща Аьлжина: 14 см. 


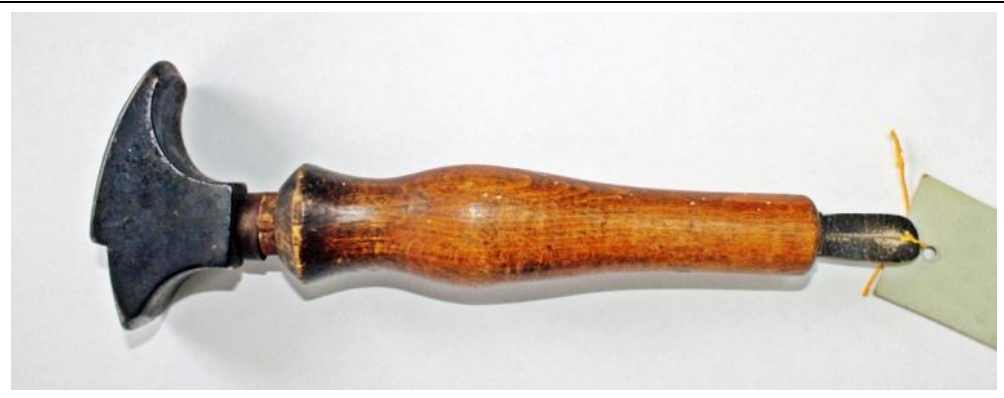

Фиг. 16. (Х)амбус -

\section{Инв. № 761 Е.М. / ОИМ-ВТ.}

Инструментьт служи за разпьване и гланциране на кожата на обувката, която преди това е захваната за кальпа с гвоздейчета. СлеА неговото загравяне, (х)амбусьт разтапя и заглажАа греса и черния воськ, които предварително са намазани върху кожата. Използва се и при полиране на табаните на обувките. Инструментьт се състоИ от Аве основни части - Аървена цилинАрична Аръжка и метален корпус, имащ фрормата на островрьха, скосена от елната страна обувка, с глаАка основа и стьпаловиАна заАница. Металната част е втикната и закрепена за дръжката посредством метален прьстен. Обща дьлжина: 19 см.

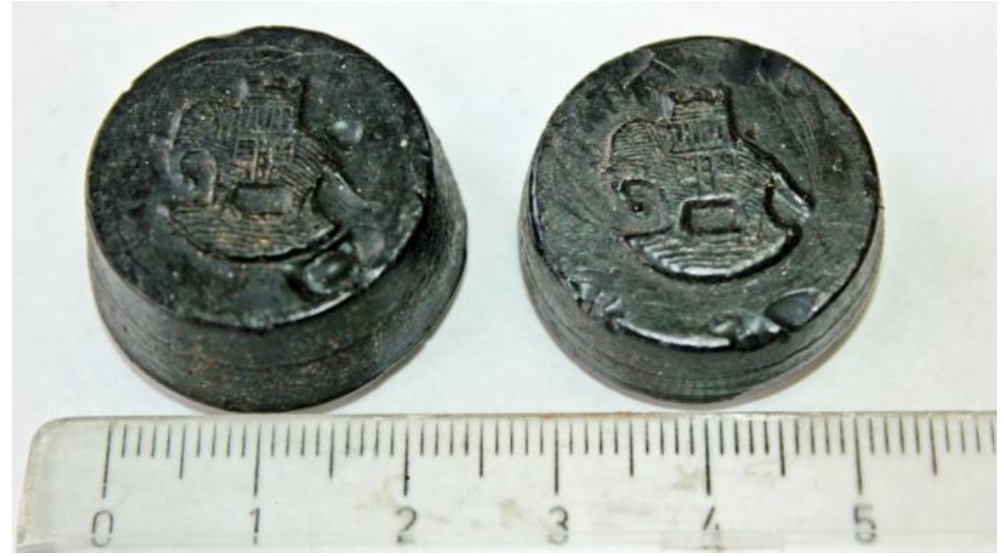

Фиг. 17. Черен восък -

Инв. № 775 E.M. / ОИМ-вт.

Използва се за сидиросване (изглаждане, полиране, гланциране) на гьона. СлеА освободения горен пласт на гьона се слага грес и черен восък, които се търкат $А$ о разтопяване. По този начин восъкът служи за гланц на табаните на обувките. 


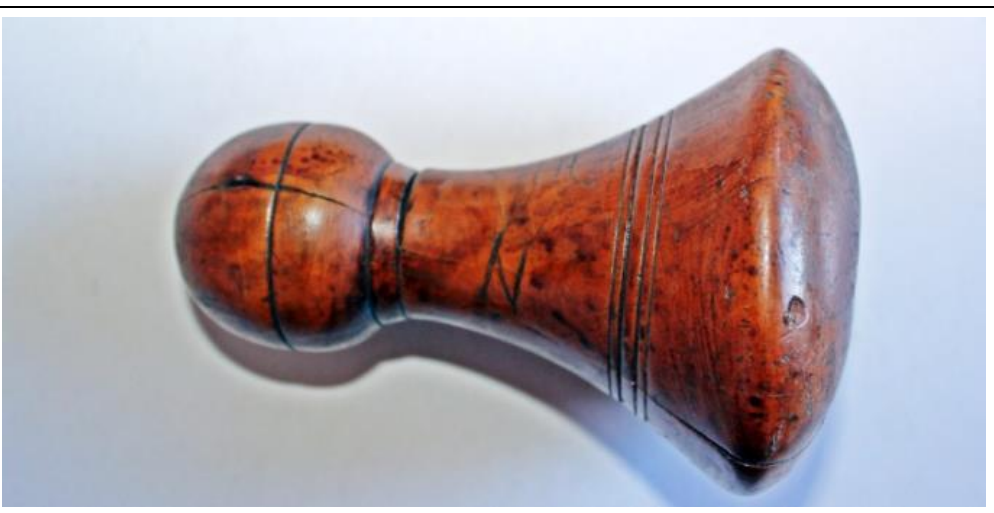

Фиг. 18. Моща -

Инв. № 136 В.сп.ф. / ОИМ-ВТ.

Използва се за полгване и притискане на кожата на обувката по начин, предотвратяващ възможността от нараняване повърхността на обработваната кожа. ОтАелно се използва и за очукване на шевове и гьон. Инструментьт е изработен от ьрво $^{6}$ и има конусовилна орорма, която завърша с крьгла

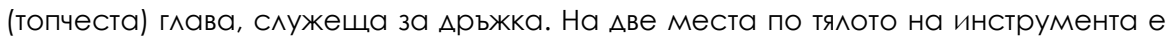
изАьлбан знакьт „N“. Височина: 12 см.

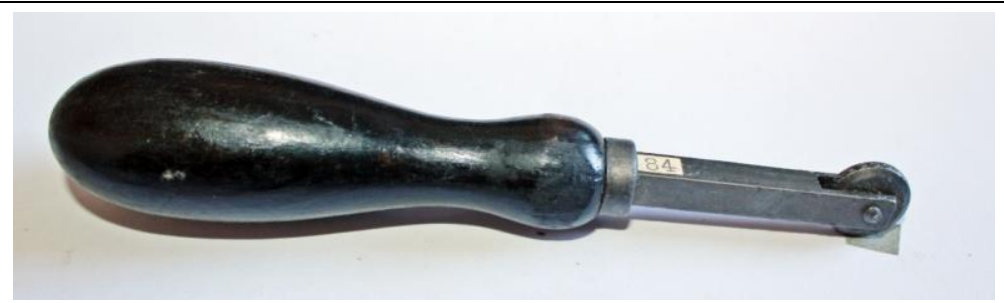

Фиг. 19. Шарик, Аекориращо колело -

Инв. № 132 В.сп.ф. / ОИМ-ВТ.

Инструментьт служи за декорация на кожата на обувката, както и за шарки върху силиросани (полирани) гьонове. Използва се слеА нагряване. Шарикът се състои от Аве основни части - крушовиАна Аървена Аръжка и продьлговата метална вилка, завършваща с малко гравирано колелще за декорация. Върху колелцето са гравирани малКи, изАаАени наА повърхността пьпчици и Аиагонални къСи Аинийки. Металната вилка е втькната и фриксирана в Аръжката, посреАством метален прьстен. Обща Аьлжина: 15 см.

${ }_{6}$ Инструментьт се среща и вьв вариант, изработен от бронз. 


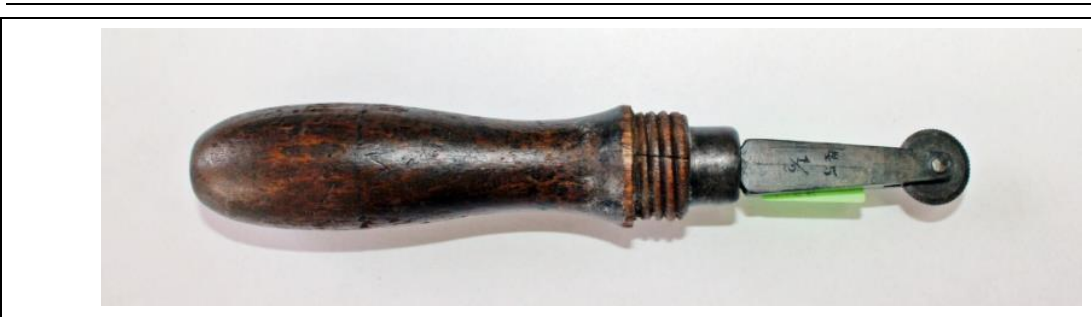

Фиг. 20. Шарик за откопиране на молел и за Аекорация -

Инв. № 764 E.M. / ОИМ-Вт.

Инструментьт служи за декорация на кожата на обувката, както и за шарки върху силиросани (полирани) гьонове. Използва се още и за откопиране на молел върху кожа или гьон. Шарикът се състои от Аве части - цилинарична Аьрвена Аръжка с резба от предната страна и плоска, п^ьтна, метална пластина, която в единия си край е с отвор, в който е поставено и занитено колелце със ситни зъбци. Аругият край на пластината е втикнат в Аървената Аръжка и закрепен с метална халка. Обща Аьлжина: 15,7 см.

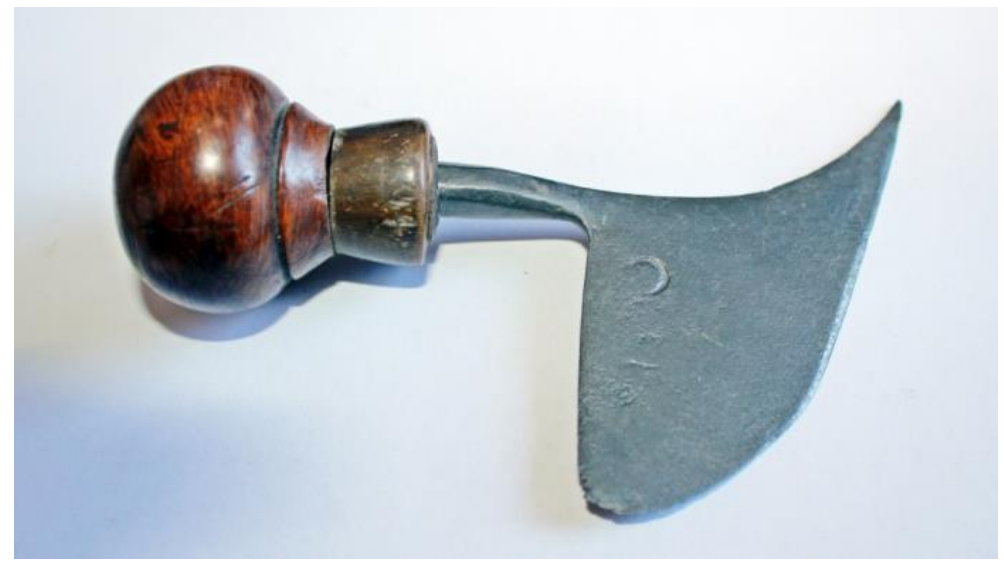

Фиг. 21. Траш-нож -

Инв. № 134 В.сп.ф. / ОИМ-ВТ.

Използва се за изтьняване /траширане/ на краищата на кожата и на гьона на

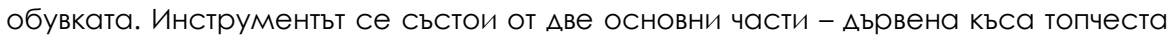
Арьжка и метално режещо тяло с крило-образна фрорма (полуелипсовилно, п^оско тяло), което е втькнато и фриксирано в Аръжката, посреАством метално Късо ^остче. От еАната страна на металното тяло е набит знак, имащ формата на полумесец. Обща Аьлжина: 13,5 см. 


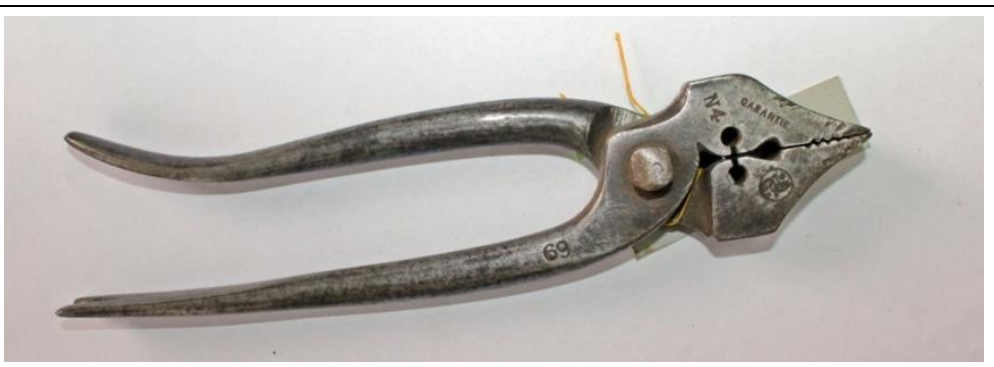

Фиг. 22. Таналия, обущарски клещи -

Инв. № 757 Е.М. / ОИМ-ВТ.

Служат за изтегляне и опьване на саята (скроено и съшито мице на обувка, преди $а$ а се натегне на кальп) върху кальпа. Инструментьт се сьстои от $а в а$ масивни метални ^оста, закривени и захванати с нит, като еАната страна образува челюстите, а другата - Аръжката. Върху клещите има налпис GARANTIE N 4 и числото 69. ОтАелно върху челюстите е инкрустиран монограм с изображение на АъB и налпис WAF. Обща Аь^жина: 20,6 см.

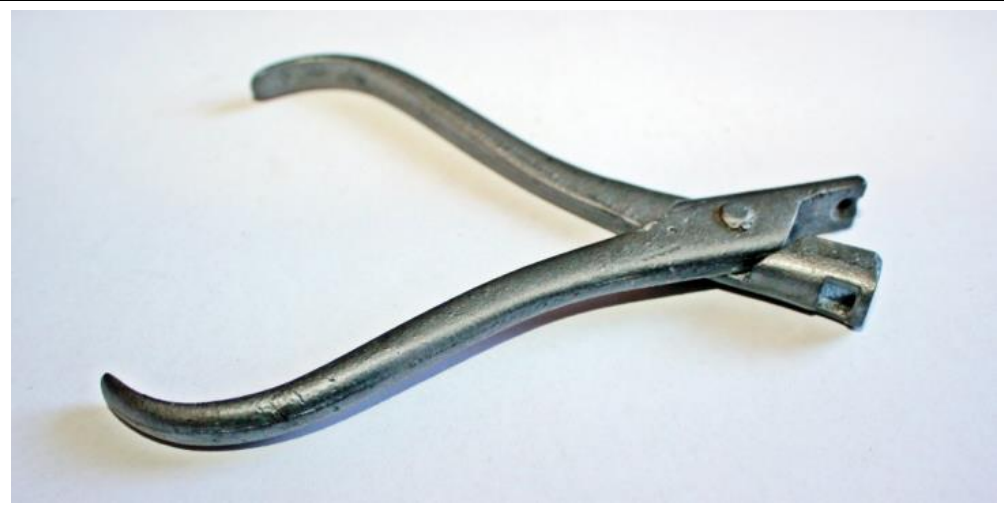

Фиг. 23. Замба-клещи -

Инв. № 135 В.сп.ф. / ОИМ-ВТ.

Клещите се използват за поставяне/махане на кабзи по/от обувките. Инструментьт се състои от Ава масивни метални ^оста, закривени и захванати с нит, като елната страна образува челюстите, а другата - Аръжката Челюстите са продьлговати, като еАната им страна преАставлява пльтно тяло с плитка Аупка, а Аругата страна има трапецовилен Аьлбок отвор. Обща Аьлжина: 13,5 см. 


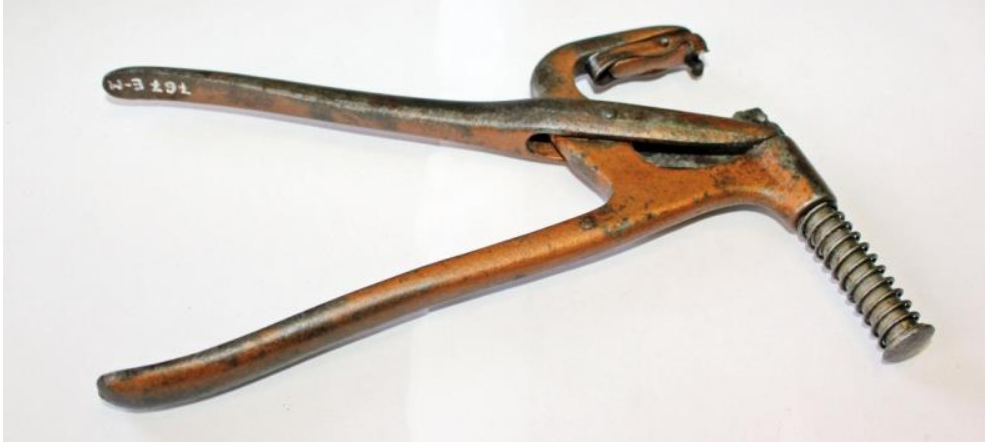

Фиг. 24. Машинка за копчета -

Инв. № 767 Е.М. / ОИМ-ВТ.

Инструментьт е изцяло метален. Работната част е полвижна и е с метални пружини около облия метален винт. Аръжките са занитени. Обща Аьлжина: $24,3 \mathrm{cM}$.

Фиг. 25. Замба -

Инв. № 763 Е.М. / ОИМ-ВТ.

Служи за ажурна украса по обувката. Тялото на замбата е метално и в цилинарична фрорма, като от енната страна е скосено и с отвори. Аьлжина: 8,6 см. Ширина: $1,3 \mathrm{~cm}$.

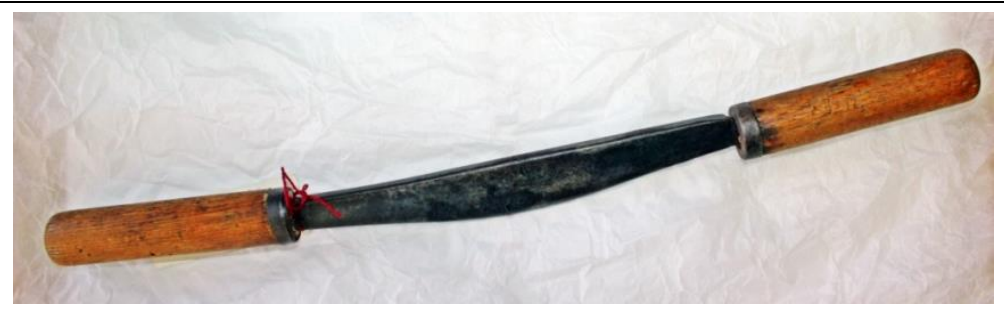

Фиг. 26. Щека -

Инв. № 765 Е.М. / ОИМ-ВТ.

Инструментьт се използва за сидиросване (изглаждане, полиране) на гьона, както и при процеса на залепването му към саята. Сьстои се от три части - метален корпус, който е втикнат и закрепен, посредством метални халки, в Аве Аьрвени Аръжки. 
Металният корпус е плосък с ^еко разширяваща се средна част и наАльжно скосено острие по Аьлгата, Аьговидна страна. Обща Аьлжина: 42,6 см. Ширина: $2,9 \mathrm{cM}$.

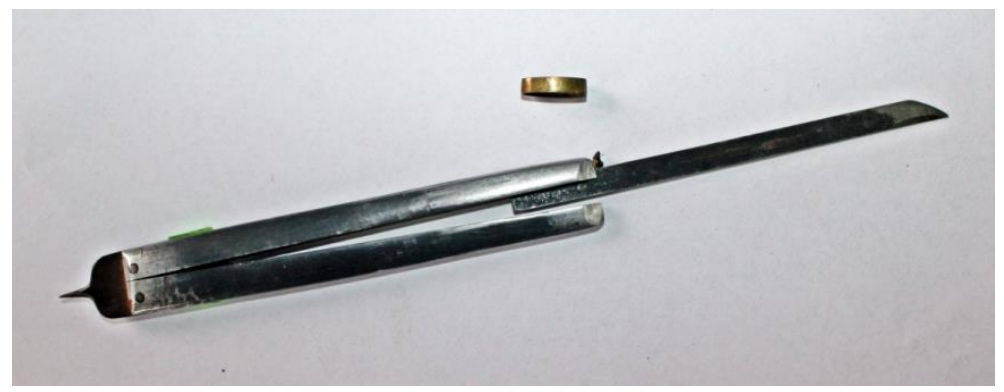

Фиг. 27. Нож за кроене -

Инв. № 747 Е.М. / ОИМ-ВТ.

Служи за рязане при кроене на кожата. Ножът се състои от три самостоятелни части - метална отваряща се Аръжка с късо шило в залницата, метално подвижно и свалящо се острие и метална халка, която захваща и пристяга Аръжката. Аръжка - Аьлжина: 14,3 см; ширина: 1,7 см. Острие - Аьлжина: 11,7 см; ширина: 7 см.

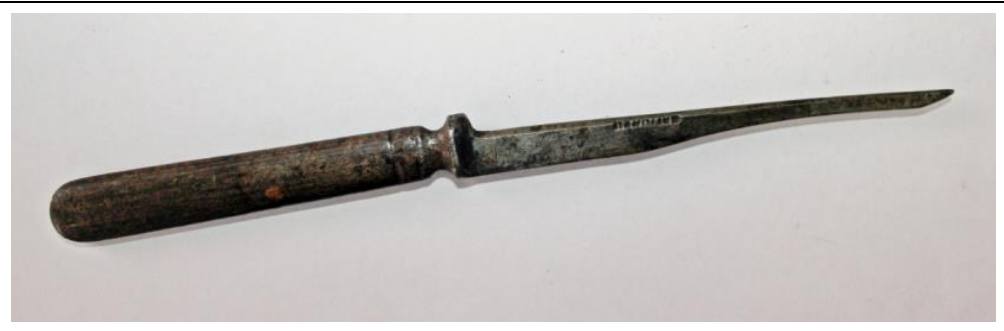

Фиг. 28. Нож, обущарски -

Инв. № 760 Е.М. / ОИМ-ВТ.

Служи за престьргване на гланца на гьона, като освобожАава горния пласт. Инструментьт е изцяло метален. Състои се от обла Аръжка и острие, което към върха се скосява стьпаловидно. Вьрху ножа, откъм острата, режеща част има налпис „А II М Р Р М“. Обща Аьлжина: 21,2 см. 


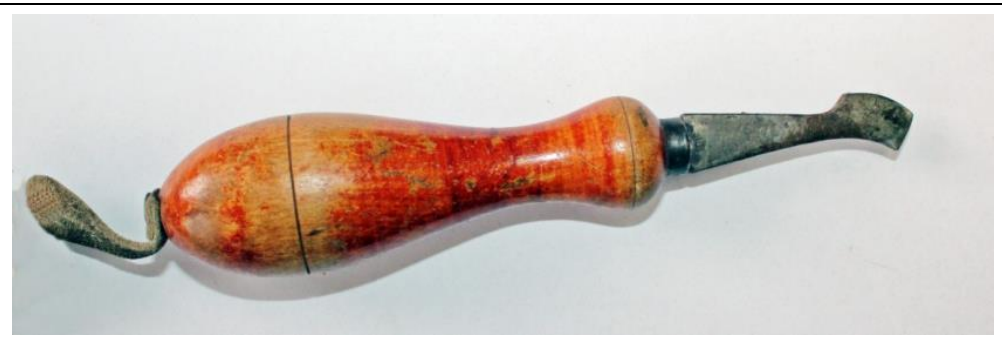

Фиг. 29. Нож-Аермезе -

Инв. № 748 Е.М. / ОИМ-ВТ.

Служи за отваряне на дермезе, т.е. прави прорези (каналчета) в гьона (на 6-8 мм от края на холилото) при шиене на полметката към обувката, за $л а$ се скрие шевьт. Инструментьт се състои от Аве части - Аьрвена крушовидна Аръжка и метален корпус, втикнат и закрепен за дръжката, посредством метална халкичка. Металният корпус завършва с продьлговато, налАъжно скосено острие. Обща Аьлжина: 16,2 см.

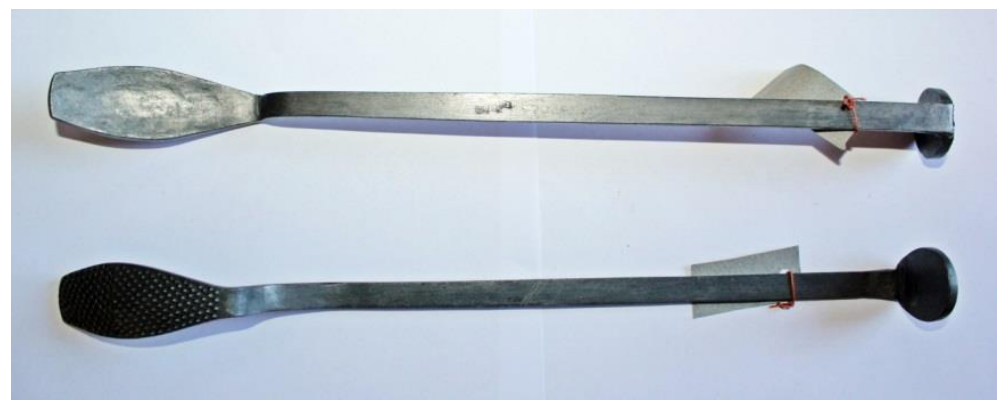

Фиг. 30.1. и 30.2.

Комплект криви раш-пили (рашпи) -

\section{Инв. № 137 В.сп.ф. / ОИМ-ВТ.}

Служат за изпиляване на клечките, които са излезли от табаните вътре в обувките.

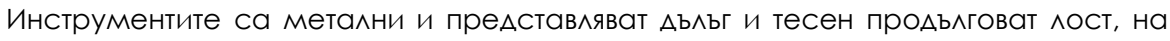
който еАиният край завършва с пила във формата на елипсовиАно „Стьпало“, а Аругият с пи^а в О-образна „петичка“. Аръжките и на Авете рашпи са маркирани с наАпис "FRANKONIA F.M.". И Авата инструмента са с еАнакви размери. Обща Аьлжина 37,5 см. „Стьпало": 3 см × 8,2 см. „Петичка": 3 см × 3,5 см. Широчина на Арьжката: 1 см. 


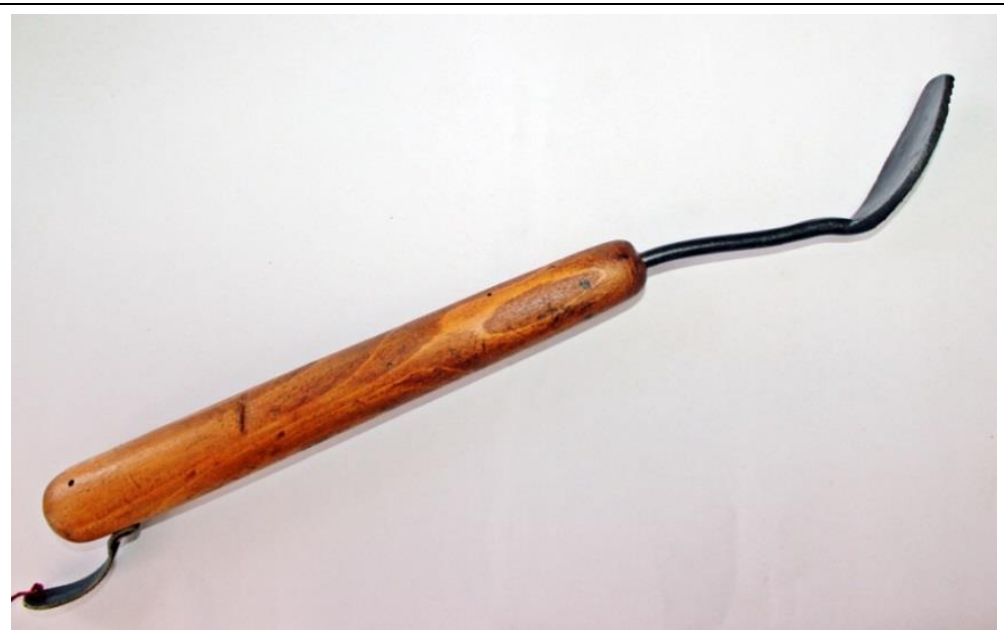

Фиг. 31. Раш-пила (рашпа), крива -

Инв. № 758a E.M. / ОИМ-ВТ.

Служи за изпиляване на клечките, които са излезли от табаните вътре в обувките. Рашпата се състои от Аве части - Аьрвена изАьлжена цилинАрична Аръжка и късо метално ^остче, завьршващо с пи^а във формата на елипсовиАно "стьпало“. Металното ^остче е втикнато в Аръжката. Обща Аьлжина: 39,2 см.

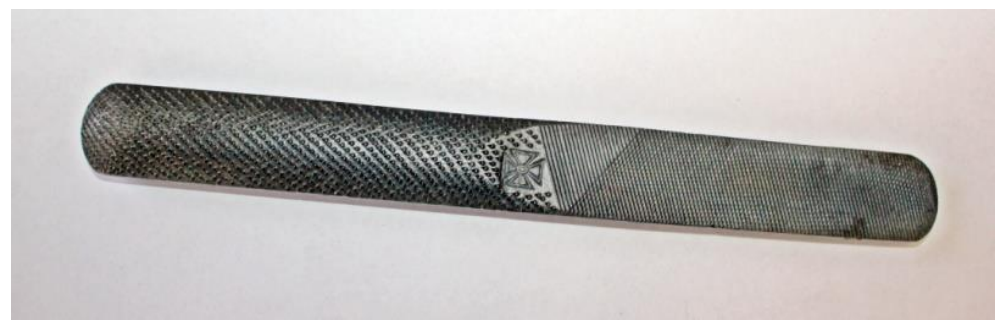

Фиг. 32. Раш-пила (рашпа), права -

Инв. № 7586 Е.М. / ОИМ-ВТ.

Служи както за изпиляване на клечките, които са излезли от табаните отвън на обувките, така и за изравняване на различни неравности по краищата на кожата. Инструментьт е изцяло метален. Няма обособена Аръжка. Всяка от страните е пи^а с различни размери и посока на пилене. Състои се от общо четири вила пили. От енната страна има врязано изображение на „крьст“. Обща Аьлжина: 23 см. Ширина: 2 см. 
Фиг. 33.1.

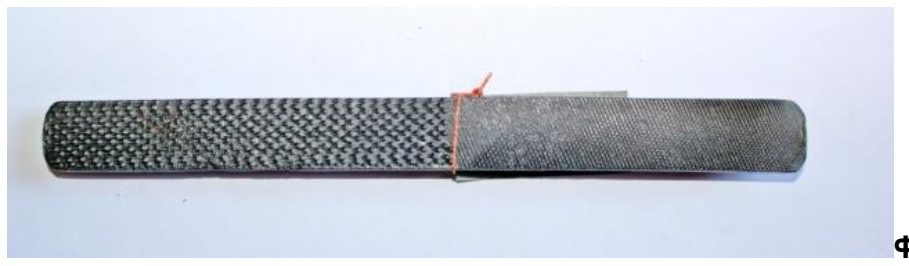

Фиг. 33.2.

\section{Раш-пила (рашпа), права -}

Инв. № 138 В.сп.ф. / ОИМ-ВТ.

Служи както за изпиляване на клечките, които са излезли от табаните отвън на обувките, така и за изравняване на различни неравности по краищата на кожата. Инструментьт е изцяло метален. Няма обособена Аръжка. Всяка от страните е пи^а с различни размери и посока на пилене. Състои се от общо четири виАа пили. ЕАна страна на инструмента е плоска, а Аругата - заоблена. Обща Аь^жина: 21 см. Ширина: 2 см.

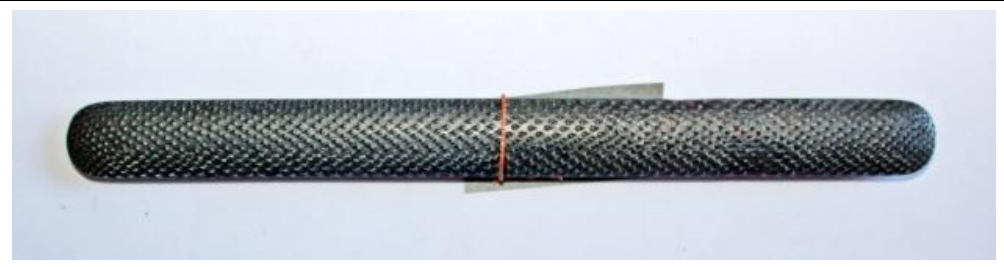

Фиг. 34. Раш-пила (рашпа), права -

Инв. № 139 В.сп.ф. / ОИМ-ВТ.

Служи както за изпиляване на клечките, които са излезли от табаните отвън на обувките, така и за изравняване на различни неравности по краищата на кожата. Инструментьт е изцяло метален. Няма обособена Аръжка. Всяка от страните е пила с различни размери и посока на пилене. Състои се от общо четири вила пи^и. Авете страни на инструмента са обли. Обща Аьлжина: 20,5 см. Ширина: $2 \mathrm{~cm}$. 


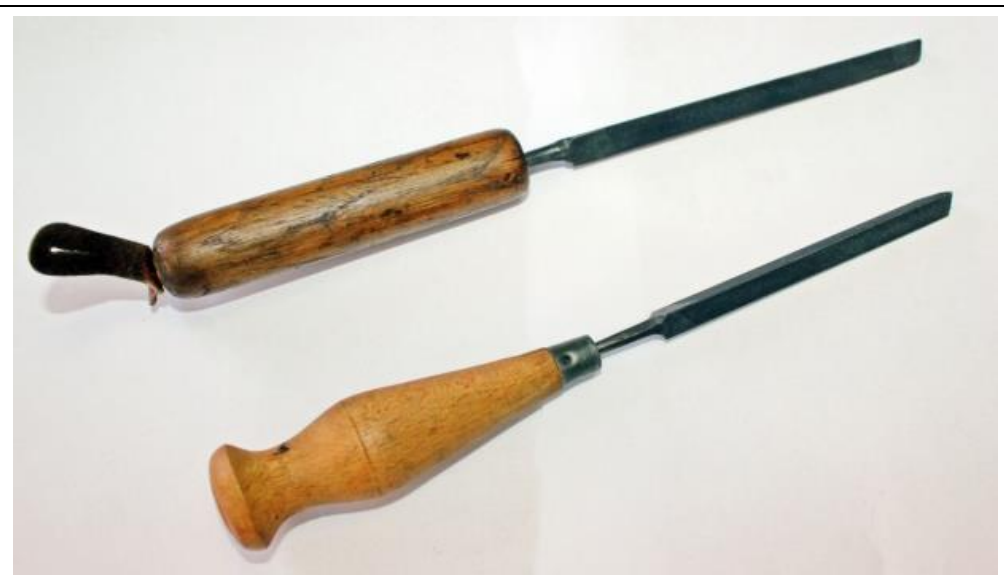

Фиг. 35. Комплект пияи, триъгъАни -

Инв. № 759а Е.М. / ОИМ-ВТ и 7596 Е.М. / ОИМ-ВТ.

Служат както за изпиляване на клечките, които са излезли от табаните отвън на обувките, така и за изравняване на различни неравности по краищата на кожата. Всяка от пилите се състои от Аве части - Аьрвена Аръжка и метален $А$ ст с триъгљно сечение, на който се намират пили с размични размери. ЕАиният от инструментите е с отчупен метален врьх, с метален прьстен за закрепяне на металната част, с конусовилна Аръжка и с обща Аьлжина: 22,9 см. Аругият е с изАьлжена цилинАрична Аръжка, завършваща с кожена окачалка и с обща $\triangle \mathrm{b} \wedge$ жна: $28 \mathrm{~cm}$.

\section{Фиг. 36. Мазол -}

\section{Инв. № 762 E.M. / ОИМ-ВТ.}

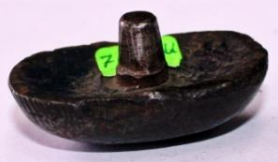

Служи за уширяване на стеснено място в обувката, което може $а$ убива на ходилото. С него се съзАава възможност за повече уАОбство при носене на новата обувка. Слага се върху кальпа. Приспособлението е метално с фрорма на елипсовиАна ґба с къса опашка (занитен винт). Аьлжина: 3,7 см. Ширина: 2,2 см. Височина 1,7 см. 


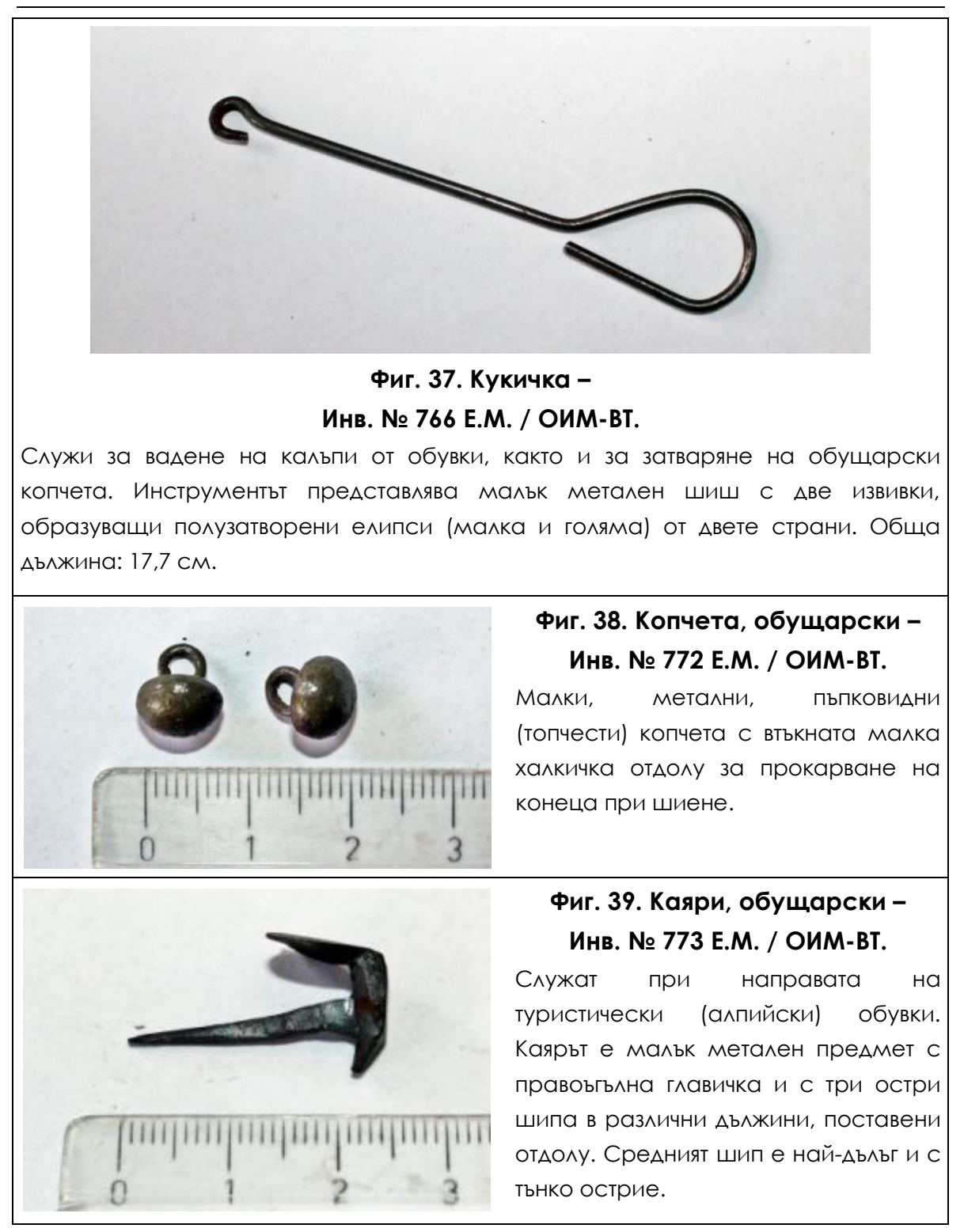




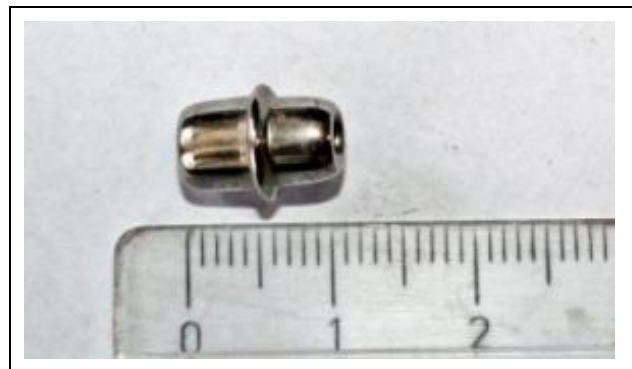

Фиг. 40. Камбанки, обущарски Инв. № 774 E.M. / ОИМ-ВТ.

Поставят се в края на връзките на обувките. Камбанката представлява никелиран мальк цилинАричен предмет, в средата обиколен с изпькнал навън ръб, а в Авата края С отвор за прокарване на врьзката.

Фиг. 41. Аима -

Инв. № 776 Е.М. / ОИМ-ВТ. Аребни гвоздейчета за капаците на обувките. Метални.
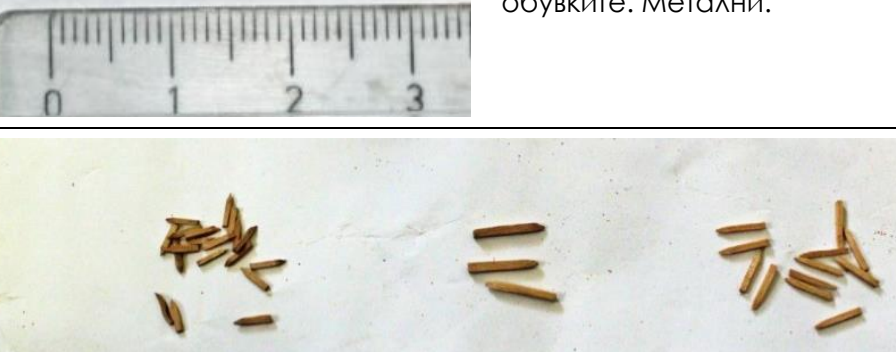

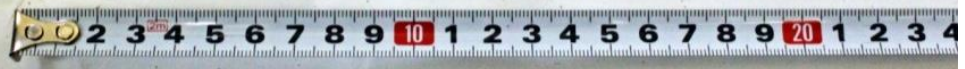

Фиг. 42. КАечки -

\section{Инв. № 248 Е.А. / ОИМ-ВТ.}

Клечките се набиват в табаните на обувките. Изработени са от Аьрво. Малките клечки са за Аетски и Аамски обувки. Големите клечки (в центьра на снимката) се наричат „кранци” и се използват при мъжките обувки. 
КУАТУРНО-ИСТОРИЧЕСКО НАСАЕАСТВО:

227

ОПАЗВАНЕ, ПРЕАСТАВЯНЕ, АИГИТААИЗАЦИЯ

TОМ 6, БРОЙ 2 (9)/ 2020

Фиг. 43. Калъпи, съответно за Аетски, Аамски и мъжки обувки Инв. № 240 E.А. / ОИМ-ВТ.

Аървени. А) Върху кальпите на Аетските обувки е изписано числото 217. Аьлжина 20 см и ширина 7,5 см.

Б) Върху кальпите на Аамските обувки са изписани числата 7, 35, 10. Аьлжина 23 см и ширина 7,5 см. В) Върху кальпите на мъжките обувки е изписано числото 269. Аьлжина $30 \mathrm{cM}$ и ширина 9,5 см.

CULTURAL AND HISTORICAL HERITAGE:

PRESERVATION, PRESENTATION, DIGITIZATION

VOLUME 6, ISSUE 2 (9)/ 2020 


\section{Фиг. 44.1. Халщи -}

\section{Инв. № 241 E.A. / ОИМ-ВТ.}

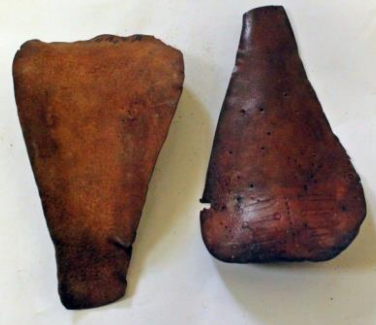

Обущарски кожени поАпАънки, които се поставят върху кальпите. Халците имат различни размери в зависимост от размера на кальпа.

Фиг. 44.2 Халци -

Инв. № 240 Е.А. / ОИМ-ВТ.

ВижАа се начиньт на поставяне на халците върху кальпите. 


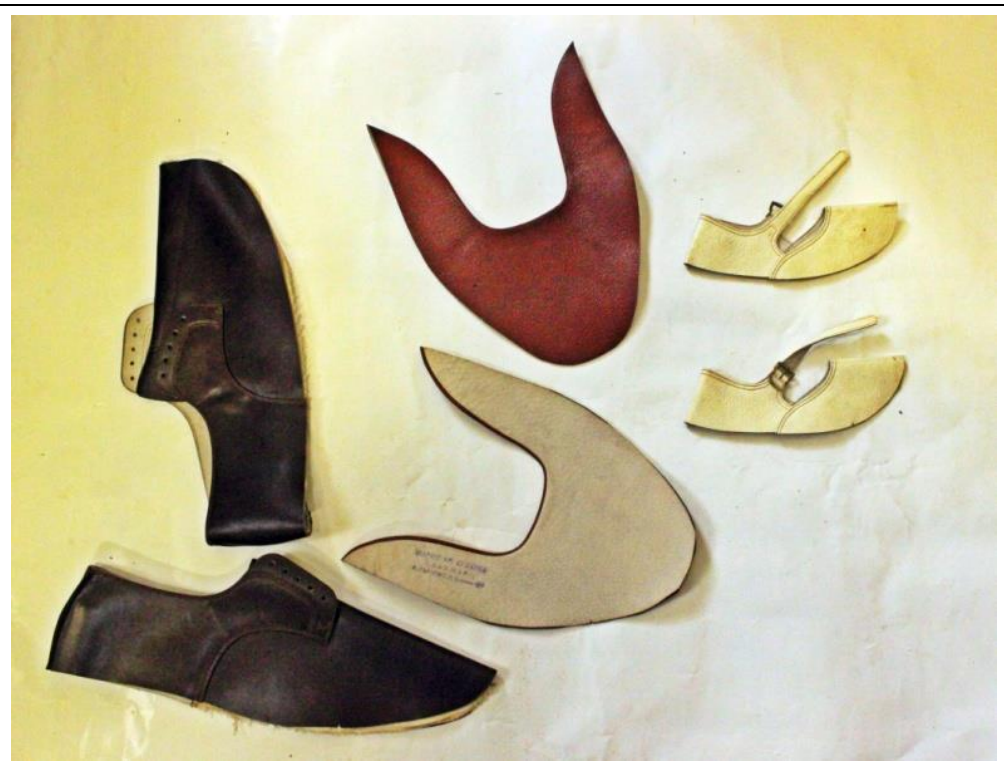

Фиг. 45. Саи -

Инв. № 242 E.A. / ОИМ-ВТ.

Горна, кожена част на обувката. На снимката са представени А) Саи за мьжки обувки в тьмно кафряв цвят. Вьрху вьтрешната страна е поставен печат с наАпис: „Марин Хр. Будаков / =обущар= / В. Търново „А. Благоев" 19". Размери: обиколка $70 \mathrm{cм}$; Б) Саи за чехли в кафряв цвят. Върху вьтрешната повърхност е поставен печат: „Марин Хр. Будаков / =обущар= / В. Тьрново „А. Благоев” 19”. Размери: Аь^жина 21 см, ширина 17,5см. В) Саи за Аетски обувки в бял цвят. Имат каишка и катарама. Вьрху вьтрешната повьрхност е поставен печат: „Марин Хр. Будаков / =обущар= / В. Търново „А. Благоев" 19". Обиколка 40 см. 


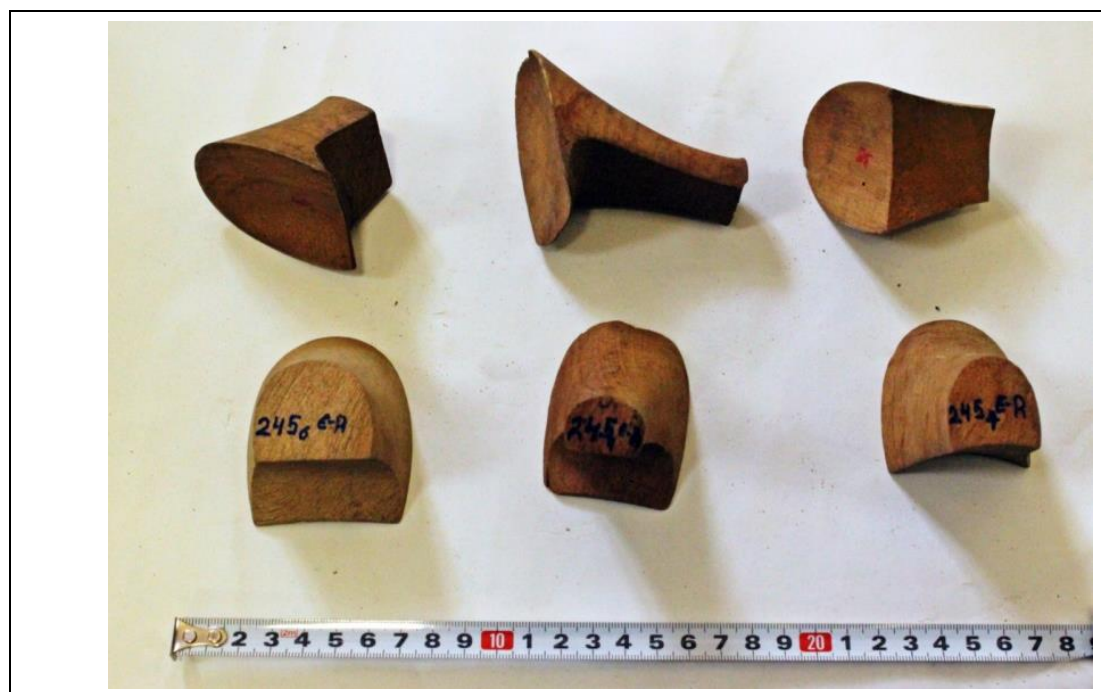

Фиг. 46. Токове за Аамски обувки Инв. № 245 E.A. / ОИМ-ВТ.

Аьрвени.

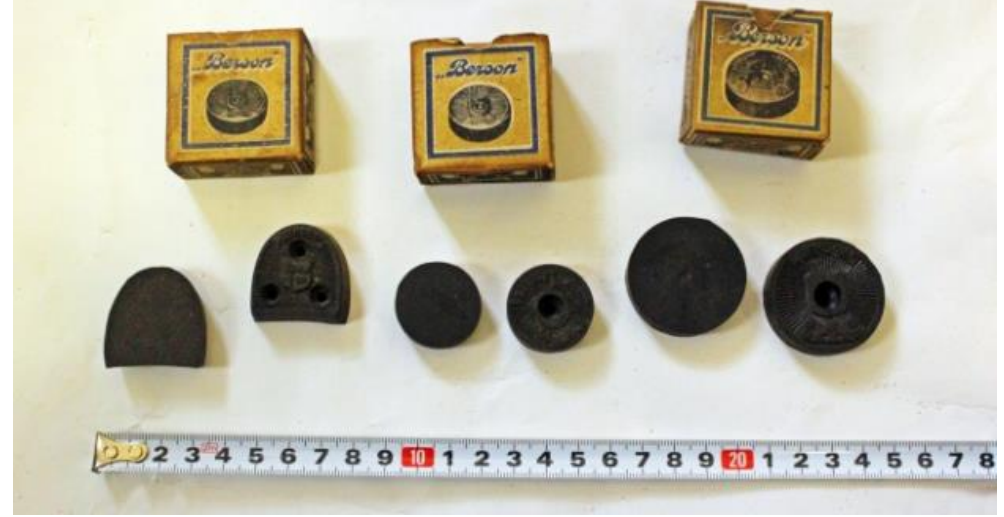

Фиг. 47. Капачета за токове -

Инв. № 244 Е.А. / ОИМ-ВТ.

Капачетата са изработени от гума. Върху мицевата повърхност на капачето е изписано Berson 4/0. Капачетата се съхраняват във ффабрични картонени кутийки „Berson". 


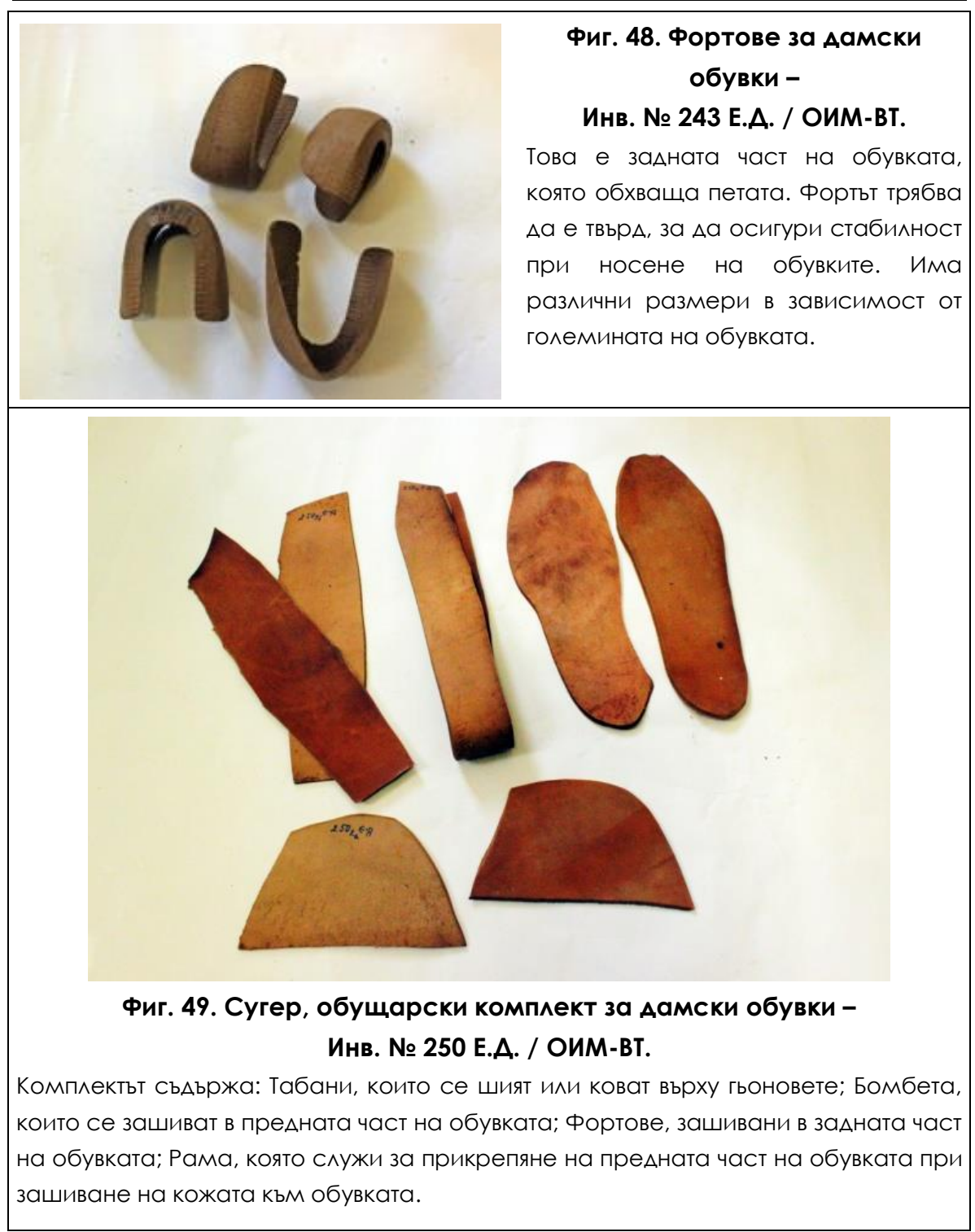




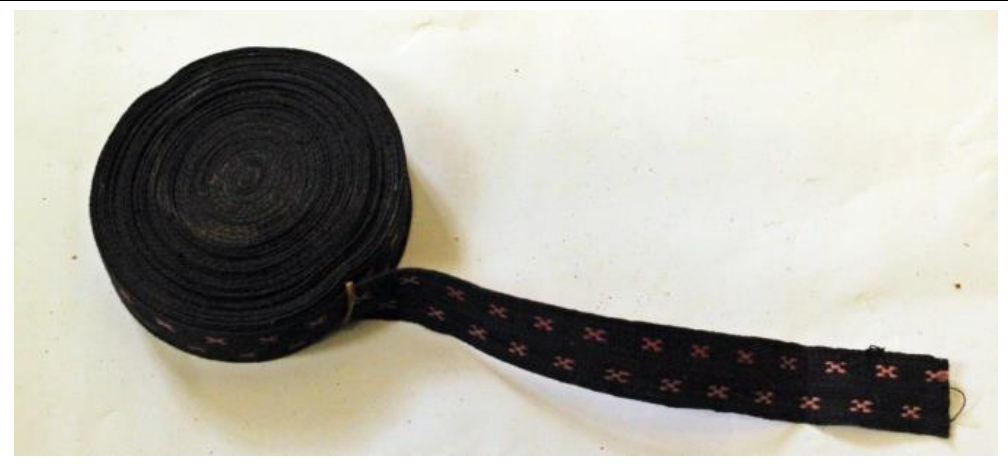

Фиг. 50. Аента -

\section{Инв. № 251 Е.А. / ОИМ-ВТ.}

П^атнена, черна с крьстата украса в розов цвят. Служи за прешиване на уши за обуване на високи затворени обувки, които обхващат глезена (чипици), както и за разкрояване с ориле (вертикална кожена ивица, която ляга върху фрорта) при ботушите. Размери: Аьлжина 8 м, ширина 35 см.

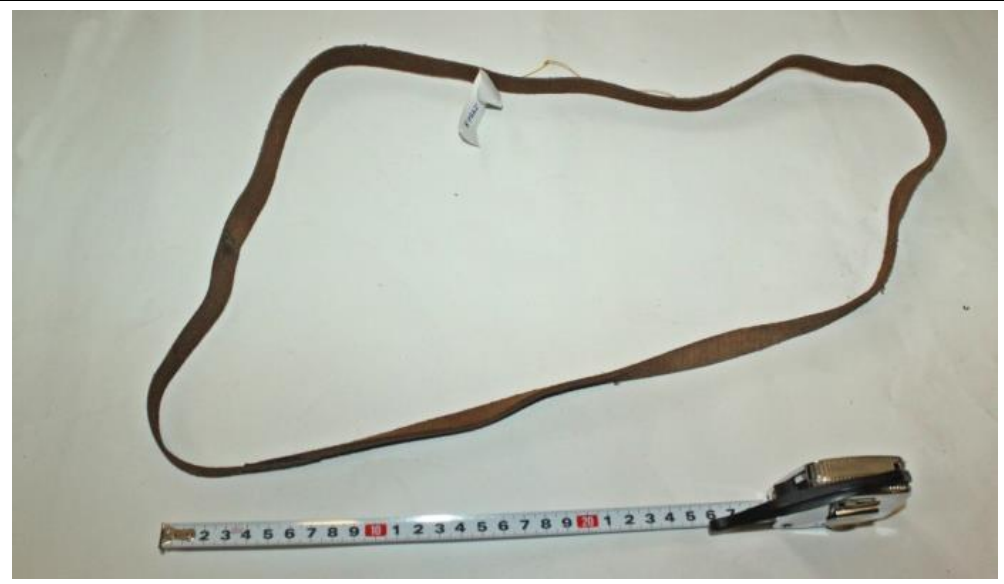

Фиг. 51. ПоАвал -

\section{Инв. № 249 Е.А. / ОИМ-ВТ.}

Служи за ориксиране и придьржане на обувка върху коляното на обущар по време на определени произволствени операции. Подвальт преАставлява кожена ^ента, на която Авата края са залепени. 


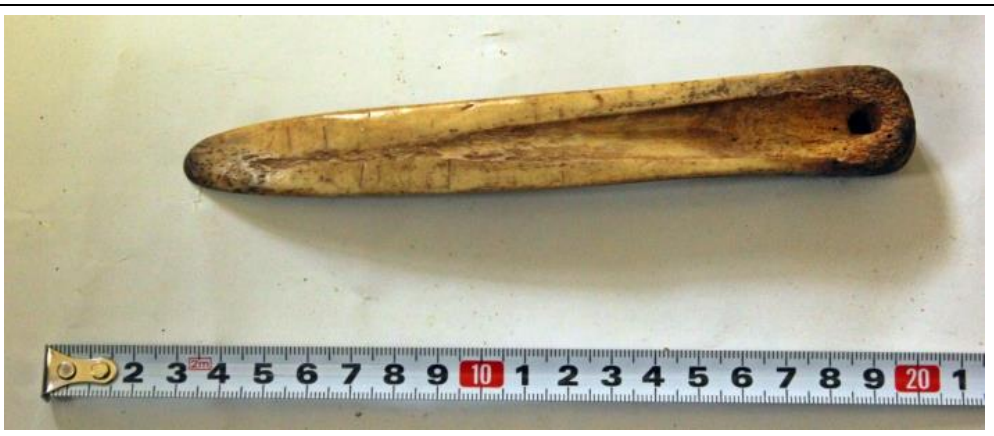

Фиг. 52. Кокал -

Инв. № 246 Е.А. / ОИМ-ВТ.

Обущарски инструмент, примитив. Служи за отваряне на дермезе, т.е. прави прорези (каналчета) в гьона (на 6-8 мм от края на холи^ото) при шиене на полметката към обувката, за да се скрие шевьт (виж фригура 29). Повърхноста на кокала е глалка. В еАиния край завършва със заострен връх, а в Аругия има пробит отвор. НаАльжно по тялото на кокала е направено и плитко каналче. Аьлжина 17 см, ширина 2,4 см.

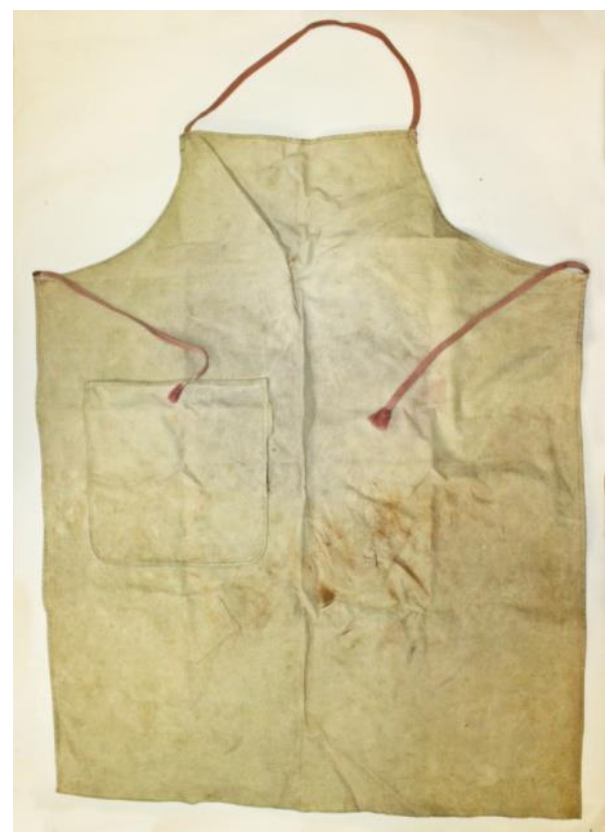

\section{Фиг. 53. Престилката на} обущаря Марин БуАаков Инв. № 247 E.A. / ОИМ-вТ.

Изработена е от брезент, в избелял от времето зелен цвят. Правоъгълна. В горния край е стеснена и сьс зашит шнур във вече избелял червен цвят. Той се премята през главата и ляга на врата на майстора. Отлелно от Авете страни на престилката също е зашит по еАин шнур. Те служат за препасване на работната дреха през крьста. На мицевата Аясна страна на престилката е пришит голям Аьлбок Ажоб. Аьлжина 78,2 см, ширина 64,5 см. 
Описаните обущарски инструменти и пособия представляват неизменна част от инвентара на всяка обущарска работилница

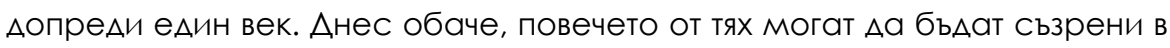
ателиетата само на малцина майстори обущари, които ги пазят като наслеАство. Аруги пьк имат спораАична употреба и в съвременността, но вильт им, материалите, от които са направени, както и тяхната функционалност и название са видоизменени и модернизирани. От Аруга страна, що се отнася Ао традиционното знание за боравене с конкретния инструмент е вьпрос на дарба, усет и майсторльк, защото, както казва Христофрор Христофроров: „Аа си занаятчия и то Аобър занаятчия трябва да ти е вродено, Аа ти се отлава. От всеки не става обущар. Ааже и кърпач не става! Колкото и странно Аа звучи кърпежът е по-труден от новото. Новото е сладка работа. Ти си го проектираш. Ти си гласиш материалите...Всичко. Аокато при кърпежа зависиш от Аругите. Оправяш грешките на Аруг, на производителите. Все пак обаче, ако някой иска Аа стане производител [на обувки - б.а.], той трябва Аа мине през такова ателиенце като туй. Аа види слабите места на обувките, $а$ види дефектите им и да се стреми да ги избегне. Тогава той ще може Аа прави обувки".

\section{АИTEPATYPA / REFERENCES}

Georgiev, G. (1979). Osvobozhdenieto i etnokulturnoto razvitie na balgarskia narod 1877-1900 (in Bulgarian). Sofia // [Георгиев, Г. (1979) Освобождението и етнокултурното развитие на българския народ, 1877-1900. София].

Nabalov, T. A. (1985). Oborudvanie predpriyatiy po individualnomu poshivu i remontu obuvi (in Russian). Moscow // [Набалов, Т. А. (1985) Оборудование предприятий по инАивиАуальному пошиву и ремонту обуви. Москва].

Popov, A. (1933). Zanayatite za obrabotka i prepabotka na kozata (in Bulgarian). Sofia // [Попов, А. (1933) Занаятите за обработка и преработка на кожата. София].

Hinkov, Hr. (1926). Zanayatchijstvoto $\vee$ Balgaria. Minalo, nastoyashte i sredstva za podpomaganeto mu (in Bulgaria). Sofia // [Хинков, Хр. (1926) Занаятчийството в Бьлгария. Минало, настояще и средства за полпомагането му. София].

Tsanov, G.; Kovachev, St.; Totevski, T. (1992). Terminologichen rechnik na zanayatite $v$ Troyanskia kraj (in Bulgarian). Sofia // [Цанов, Г., Ковачев, Ст., Тотевски, Т. (1992) Терминологичен речник на занаятите в Троянския край. Сосрия] 


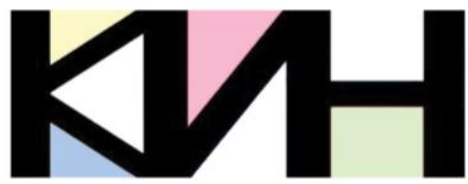

КУАТУРНО-ИСТОРИЧЕСКО НАСАЕАСТВО:

ОПАЗВАНЕ, ПРЕАСТАВЯНЕ, АИГИТААИЗАЦИЯ

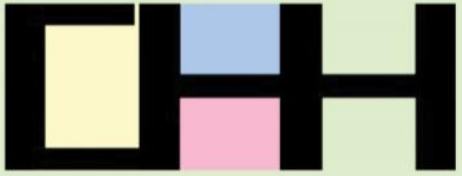

CULTURAL AND HISTORICAL HERITAGE: PRESERVATION, PRESENTATION, DIGITIZATION
Материалите в сборника са обект на авторско право. Разрешава се безвъзмезАното ползване на техни електронни/ хартиени копия само за лична употреба или обучение, при пь^но цитиране на текущата страница и слеА писмена декларация от цитиращия за мипса на търговски намерения.

(с) Авторски колектив, 2020

Техническо реАактори: Калина Сотирова-Вълкова Николай Ноев Паска^ Пиперков

\section{Editors}

Petko St. Petkov

Galina Bogdanova

This work is subject to copyright. Open and free of charge use of digital/hard copies of publications is granted only for personal or educational use, with full citation of the current page, and after written declaration of the quoting side for notcommercial Intention.

(C) Authors` Group, 2020

Technical editors:

Kalina Sotirova-Valkova

Nikolay Noev

Paskal Piperkov

НАЦИА регистрационен № 1209

Научна пореАица: том 6, брой 2 (9)/2020

Science series: vol. 6 , issue $2(9) / 2020$

NCID Registry No. 1209

www.math.bas.bg/vt/kin

ISSN: 2367-8038 